\title{
21st Century Supply Chain Management: A Multiple Case Study Analysis within the UK Aerospace Industry
}

\author{
Graham Manville * \\ Director of Employability \& Innovation \\ Senior Lecturer Business \& Management \\ Norwich Business School, University of East Anglia \\ Norwich Research Park \\ Norwich NR4 7TJ (UK) \\ Email: G.Manville@uea.ac.uk
}

\author{
Thanos Papadopoulos \\ MBA Director at Kent Business School \\ Professor of Information Systems and Operations Management \\ Kent Business School, University of Kent \\ Canterbury CT2 7PE \\ Email: A.Papadopoulos@kent.ac.uk
}

\begin{abstract}
Patrizia Garengo
Associate Professor of Performance management

Department of Industrial Engineering

University of Padua

Via Venezia 1, 35131 Padua, Italy

Email: patrizia.garengo@unipd.it
\end{abstract}

* Corresponding author 


\begin{abstract}
In recent years, to stimulate the development of Lean Supply Chain Management (SCM) in SMEs, the UK aerospace industry has developed a change programme named "Supply Chains for the 21st century" (SC21). This programme promotes the use of a simple standard improvement framework, which defines performance goals and standardizes the approaches and tools for continuous sustainable improvement. However, its effective impact on Lean SCM and performance measurement systems (PMS) has not been widely covered in the literature. Adopting a qualitative research methodology approach, this study investigates five significant organizations to explore and contribute to knowledge on Lean SCM and PMS challenges related to the adoption of the SC21 programme.

From an academic point of view, the paper highlights the key role of SC21 in accelerating the competitiveness of the aerospace industry by fostering managerial development of supply chain partners. In particular, it highlights the importance of PMS as well as collaboration between supply chain partners for efficient and effective SCM. From a practitioner's perspective, the SC21 performance award is highlighted as a very successful approach in bridging the gap of differing agendas between supply chain partners. SMEs, with support from their larger supply chain partners, can embrace performance measurement practices to improve their performance. More established SMEs with a headcount of more than 50 employees are capable of developing and documenting strategic plans and more sophisticated PMS.
\end{abstract}

Keywords: Supply Chain Management, Lean, Performance Measurement, SME, Management Capability 


\section{Introduction}

In recent years, academics and practitioners have recognised particular relevance to SCM in the aerospace industry (Braziotis et al. 2017; Ruiz-Benitez et al. 2018), where emphasis on cost reduction has brought uncertainty to the robustness of delivery schedules. In the aerospace sector prime contractors, usually named "Primes", play a key role in supply chain management as they are ultimately responsible for the whole project to their client (usually a government agency). They have responsibility for coordinating all of the tiered sub-contractors (usually a large number of SMEs) and they exert high downward pressure on profit margins for SMEs to minimise total cost and enhance quality and customer satisfaction (Spekman and Davis 2016). As a consequence, in this industry SMEs become especially exposed to global competition and they are compelled to achieve world-class standards or risk losing market share (Funo et al. 2011; Quayle, 2003).

To face the increasing global competition, for many years, the aerospace industry has embraced quality management principles, advocating the use of Lean supply chains (Lamming, 1993). Consequently, the lean principles have been adopted within the aerospace organizations (Browning and Heath 2009; Pešalj et al. 2018; MartínezJurado and Moyano-Fuentes, 2014; Thomas et al 2016). However, the evidence of externally validated lean supply chain performance is not adequately covered in the literature. There is evidence of self-assessed lean systems within the aerospace sector (Hallam and Keating, 2014). Notwithstanding, the literature recognizes that the successful adoption of lean principles requires a holistic and collaborative strategic vision instead of an adoption focused on specific improvement initiatives (Hines et al. 2004); the investigations about key determinants of lean are still mainly focused on production environment (Martínez-Jurado and Moyano-Fuentes, 2014) Traditionally, the literature suggests Critical Success Factors (CSFs) and Key Performance Indicators (KPIs) supporting performance improvement (Chae, 2009; Suh and Kwon, 2006). Some models are identified for analysing the effects of product variety on performance (Thonemann and Bradley, 2002), as well as addressing issues around performance measurement (Ruiz-Benitez et al. 2018; Haque and James-Moore, 2005; Peters et al 2008). Since 2000s, researchers propose to combine Six Sigma and Lean strategy to favour performance improvement (George, 2002; Timans et al. 2012) and a number of scholars investigated Lean Six Sigma (LSS) also referring to aerospace industry due to 
its recognized appropriateness to solve complex cross-functional problems and reduce variations in manufacturing processes (Antony et al., 2012, Thomas et al. 2016). This approach integrates both lean and Six Sigma approaches to enhance business performance. On one hand, Lean principles support companies in reducing and removing waste, on the other hand, Six Sigma favours the focus on the Critical to Quality (CTQ) issues that affect the quality of products and/or services (Drohomeretski et al. 2014; Assarlind et al 2013; Zhang et al. 2015). A numbers of studies investigate the use of the Define, Measure, Analyse, Improve and Control (DMAIC) cycle as the central driver to the delivery of LSS and its improvement approach is the data-centric process (Pande, Neuman, \& Cavanagh, 2014). However, most of them do not show the systematic application of the Lean thinking cycle.

Literature has shown support for six sigma in an SME context (Antony et al. 2008) but there are major challenges implementing six sigma in a low volume SME context. A study of a Spanish SME supporting six sigma with low volumes applied DMAIC principles to the painting task made a bold claim about the opportunities for low volume six sigma in SMEs but was inconclusive (Garrido-Vega et al. (2016). Another study of German SMEs looking at human aspects of sigma in SMEs acknowledges the lack of empirical research in this area (Shokri et al, 2016).

As shown by Thomas et al (2016), "LSS applications are primarily focused on quality improvement where improvements in throughput and overall business improvement are claimed as a result of resolving the Critical to Quality issue at hand". Moreover, despite the recognized relevance of LSS approach, some scholars highlight the need for further investigations to favour the development of rigorous performance measurement to both establish a strategic baseline and measure improvements (Kumar et al. 2006; Chakravorty and Shah 2012).

Notwithstanding a great deal of studies describes LSS one of the most effective approach for improving quality in both the manufacturing and SMEs (Knapp, 2015; Algassem et al., 2014; Bhat et al., 2014) some studies highlight difficulties in its implementation particular in SMEs. To date small and medium organization studies are mainly focused on the mechanistic issues related to the implementation of the DMAIC methodology. While a more strategic perspectives is recognized useful to manage effective performance improvement it is often neglected (Prashar, 2014; Kaushik et al., 2012; Antony 2012; Wang and Chen, 2012). Some research highlight a number of 
barriers to the successful implementation of LSS, particularly in manufacturing SMEs. The most relevant are their resistance to change, organisational culture and the lack of managerial and technical skills (Prashar, 2014; Antony, 2012; Aboelmaged, 2011; Kumar and Antony, 2008). In particular, SMEs suffer from a lack of confidence in using technical and statistical tools required by LSS (Thomas and Barton, 2006).

Since 2000s, literature highlighted the need to embrace a holistic view of performance measurement system, to favour performance improvement in numerous sectors among which aerospace industry (Neely et al 2000). A number of studies investigated PMS as a balanced and dynamic system that is able to support the decision-making process by gathering, elaborating and analysing information in both large and small and medium organization (Garengo et al 2005; Smith and Bititci, 2017). However, few empirical research studies investigate its effective adoption in aerospace organization. A key driver of this has been the concept of the "supply chain for the $21^{\text {st }}$ century" Programme (SC21, 2016), but poor empirical studies investigate its impact on both lean SCM and PMS. In order to fill the above research gaps, this paper investigates the research question:

What are the challenges related to the adoption of the SC21 programme to improve lean supply chains and PMS in the UK aerospace industry?

The paper is structured as follows: after a brief review of the literature regarding lean SCM and performance measurement (Section 2), the research methodology of the paper is presented (Section 3). This is followed by the description and discussion of the case study results (Sections 4 and 5). The final section (Section 6) concludes the paper.

\section{Performance measurement and lean SCM}

A watershed study relating to performance measurement, the publication "Relevance Lost" by Johnson and Kaplan (1987), argues that organisations should not solely rely on financial metrics as they are effectively lagging indicators. In 1999, a study by Neely (1999) identifies over 3,600 articles published between 1994 and 1996 on performance measurement, coining the phrase "the performance measurement revolution". To respond to the numerous criticisms to the traditional performance measurement approach, holistic performance frameworks have evolved to promote strategic 
alignment, focus on the creation of customer value, process view, etc. Such popular frameworks include the Balanced Scorecard (Kaplan and Norton, 1996) and the European Foundation for Quality Management (EFQM) Excellence Model, also known as the Business Excellence Model (BEM) (Conti, 2007; Dahlgaard et al. 2013; EFQM, 2018). These frameworks have traditionally been common in larger organisations and not widely adopted by SMEs (Machado et al 2018). The study by Garengo et al. (2005) identifies the reason for the dearth of performance measurement frameworks in SMEs, i.e., the lack of resources and capability plus a perception that they are too bureaucratic and not relevant to the context of an SME. Instead, they find that measurement metrics tend to be limited to operational activities (ibid). Some SME research highlights the role of bureaucracy, cultural barriers and governance structure (Heinicke, 2018) in lean adoption and subsequently on how performance measures are used. However, when adopting lean, it is vital for organizations to look externally and find ways of collaborating and coordinating with partners and ensuring that the supply chain is both efficient and responsive to the environmental stimuli (Thakkar et al. 2013).

Plenty of literature on SCM deals with performance measurement metrics such as SCOR (Huan et al., 2004; Dissanayake and Cross,2018).

Even if the key role recognised to lean supply chain management (SCM), a number of organization fail in adopting the effective performance measures and the metrics required to achieve the lean SCM objectives. As Hanson et al. (2011) highlighted the alignment of an organisation's activities with its strategies favour the competitive advantage, and, consequently to effective manage lean supply chains it is necessary to understand and manage the overall company performance. A mainly operational set of measures lacking linkage to Prime Contractors are not enough to face the changing organizational environments caused by globalisation and requiring leaner SCM.

Often companies have not succeeded in maximising their supply chain's potential because theirs performance measurement goals are not aligned with organisational goals (Gunasekaran et al., 2004; Saleheen et al., 2018)

\subsection{Supply Chain for the $21^{\text {st }}$ Century (SC21)}

In the last few years, the Trade Association and Regulation Body for the aerospace industry (TARB) has proposed a programme for performance measurement and based on the EFQM (Conti, 2006; EFQM, 2018). It is an alternative to the SCOR model (Huan 
et al. 2004), known as "Supply Chains for the $21^{\text {st }}$ Century" (SC21, 2019) and designed to improve competitiveness within the whole supply chain from prime contractor to the SME suppliers. The SC21 programme aspires to be a major step forward in achieving organisational improvement and effectiveness across the aerospace supply chain using the principles of Total Quality Management (TQM). It seeks to address the previous shortfalls of TQM implementations where tools and techniques were given credence whilst lip service was paid to the softer elements such as management commitment, leadership and culture (Powell, 1995). In addition, it seeks to mitigate the challenges faced by SMEs in adopting overarching performance improvement frameworks by stakeholder partnerships across the supply chain (SC21, 2019).

The perception of the supply chain partners, including the trade association which coordinated the SC21 programme with more than 800 participating SMEs, was that quality control systems such as ISO9001 and AS9100 were essential for guaranteeing quality assurance. However, these were effectively compliance and conformance tools rather than facilitating organizational performance improvement. The SC21 programme requires SMEs, and other supply chain partners, to satisfy the independent assessor against four categories, i.e., (1) demonstrating a Continuous Improvement Sustainability Plan (CISP), (2) deployment and scoring of the EFQM framework by the independent assessor, (3) achieving over $90 \%$ on the on-time delivery in full KPI and (4) over 98\% on the right first time KPI (SC21, 2019). The use of these assessment criteria identifies three categories of award (bronze, silver and gold) as shown in Table 1. Taking part in this programme, some SMEs went beyond the requirement of SC21 and implemented a Balanced Scorecard (BSC) within their organization. The deployment of the SC21 Business Excellence Model within SMEs partially conflicts with the findings of the work by Garengo et al. (2005), as the manufacturing SMEs within the aerospace defence sector are not only measuring performance but also using PMS frameworks. 


\begin{tabular}{|c|c|c|l|l|}
\hline & \multicolumn{4}{|c|}{ Requirement for SC21 } \\
\hline Award Level & $\begin{array}{c}\text { Improvement } \\
\text { Programme }\end{array}$ & EFQM Score & $\begin{array}{l}\text { On-time delivery } \\
\text { in full (OTDIF) }\end{array}$ & $\begin{array}{l}\text { Right first time } \\
\text { (RFT) }\end{array}$ \\
\hline Gold & $\begin{array}{c}\text { Plan progressed } \\
\text { with regular } \\
\text { reviews }\end{array}$ & $\begin{array}{c}\text { Excellence } \\
\text { level }>500\end{array}$ & $>99 \%-100 \%$ & $>99.9 \%-100 \%$ \\
& & $\begin{array}{c}\text { Excellence } \\
\text { level }>400\end{array}$ & $>95 \%-<99 \%$ & $>99.5 \%-99.9 \%$ \\
\hline Silver & & Framework & $>90 \%-<95 \%$ & $>98 \%-<99.5 \%$ \\
& & deployed & & \\
\hline
\end{tabular}

Table 1: SC21 Award Scoring Process (SC21, 2019)

The above literature highlights a dearth of literature discussing the relationship between lean SCM and PMS. The literature has not paid enough attention to the study of softer, non-financial issues as partners work together to co-create customer value. A comprehensive study of 30 LSCM frameworks was conducted by Jasti and Kodali (2015) which highlighted incoherent application to develop LSCM frameworks as well as a lack of studies involving practitioners. For lean SCM to be effective, Jasti and Kodali (2015, p. 1052) recommend that "clients within the supply chain should work together to achieve joint goals". They attribute the lack of awareness and ineffective implementation processes as the key determinants of failure of organizations in achieving Lean SCM. These gaps support the definition of the above research question.

\section{Research Methods}

The research adopts a qualitative methodology (Lincoln and Guba, 1985; Yin 2014). A multiple case study approach was chosen to gain a deeper understanding of the lean supply chain management and PMS in organizations adopting SC21. According to Eisenhardt (1989), case study research provides benefits such as novelty, testability and empirical validity. In addition, it "is particularly well-suited to research areas where the theory is deemed inadequate" (ibid, p. 549). Five organizations, belonging to the UK defence aerospace supply chain within the United Kingdom, were selected as case study organizations comprising three SMEs, with SC21 accreditations supplying precision 
component parts, one aerospace Prime Contractor and a trade regulatory body. SMEs, especially precision component part suppliers, are included as they are recognized to be a vitally important part of the aerospace supply chain and their study is essential to understand the challenges related to the SC21 programme in the aerospace industry. In order to collect empirical data, fifteen semi-structured interviews were carried out. Each interview took approximately 45 minutes on average and involved employees with different roles (Table 2).

\begin{tabular}{|c|c|c|}
\hline Case Organization & $\begin{array}{l}\text { SC21 } \\
\text { Accreditation }\end{array}$ & Position held by interviewees \\
\hline $\begin{array}{l}\text { Trade Association and Regulatory } \\
\text { Body (TARB) for SC21 }\end{array}$ & N/A & $\begin{array}{l}\text { Managing Director (MD) } \\
\text { Senior Project Manager } \\
\text { Project Consultant }\end{array}$ \\
\hline $\begin{array}{l}\text { Prime Contractor - Major } \\
\text { contractor to the aerospace industry }\end{array}$ & N/A & Supply Chain Director \\
\hline $\begin{array}{l}\text { SME1 - Employs } 60 \text { people } \\
\text { Manufactures precision-engineered } \\
\text { component parts }\end{array}$ & Bronze & $\begin{array}{l}\text { Managing Director } \\
\text { Operations Manager } \\
\text { Quality Manager } \\
\text { Production Manager } \\
\text { Works Manager } \\
\text { Production Engineering Manager }\end{array}$ \\
\hline $\begin{array}{l}\text { SME2 - Employs } 25 \text { people } \\
\text { Manufactures precision-engineered } \\
\text { component parts }\end{array}$ & Bronze & $\begin{array}{l}\text { Managing Director } \\
\text { Works Manager } \\
\text { Team Leader }\end{array}$ \\
\hline $\begin{array}{l}\text { SME3 - Employs } 20 \text { people } \\
\text { Manufactures precision-engineered } \\
\text { component parts }\end{array}$ & Silver & $\begin{array}{l}\text { Managing Director } \\
\text { Works Manager (the Works Manager was } \\
\text { the expert on SC21 in this organization) } \\
\text { Operator }\end{array}$ \\
\hline
\end{tabular}

\section{Table 2. Interviewees per Organization and Positions Held}

Interviews were audio-recorded and transcribed ad-verbatim. Lincoln and Guba (1985, p. 235) recommend that "a dozen or so interviews, if properly selected, will exhaust most available information; to include as many as twenty will surely reach well beyond the point of redundancy". The aim was to obtain the views of the strategic decision makers regarding their use of lean SCM and PMS. The interviewees were selected 
because of their understanding and expertise of lean and PMS and their involvement in the accreditation of SC21 within their own organization. The interview questions were related to the topics to the extent of the strategic perspective adopted by the SMEs, their PM practices as well as evidence of lean, supply chain management and related challenges to those issues. As recommended by Meredith (1998), to strengthen this empirical analysis, secondary data in the form of the organizations' documents (particularly strategy documents and performance reports), minutes of meetings and public information were also used to support the interviews and to achieve data triangulation as suggested.

Transcribed data were analysed manually following "three concurrent flows of activity: data reduction, data display and conclusion drawing/verification" (Miles and Huberman (1994 p. 10) and paying attention also to the structuring and the de-contextualizing of the data as prescribed by Collis and Hussey (2003). In particular, data were assigned broad initial codes that were refined as research continued. Emergent themes were identified through reviewing field-notes and interview data, and supplementary codes emerged during this subsequent analysis. The emerging themes were further refined as the process continued, thus building the analysis incrementally.

\section{Research Findings}

The empirical investigation analysed three main key lean SCM themes, i.e., strategic planning, PMS and lean management in an SME context. A summary of the findings is shown in Table 3 and discussed in the next three subsections. 


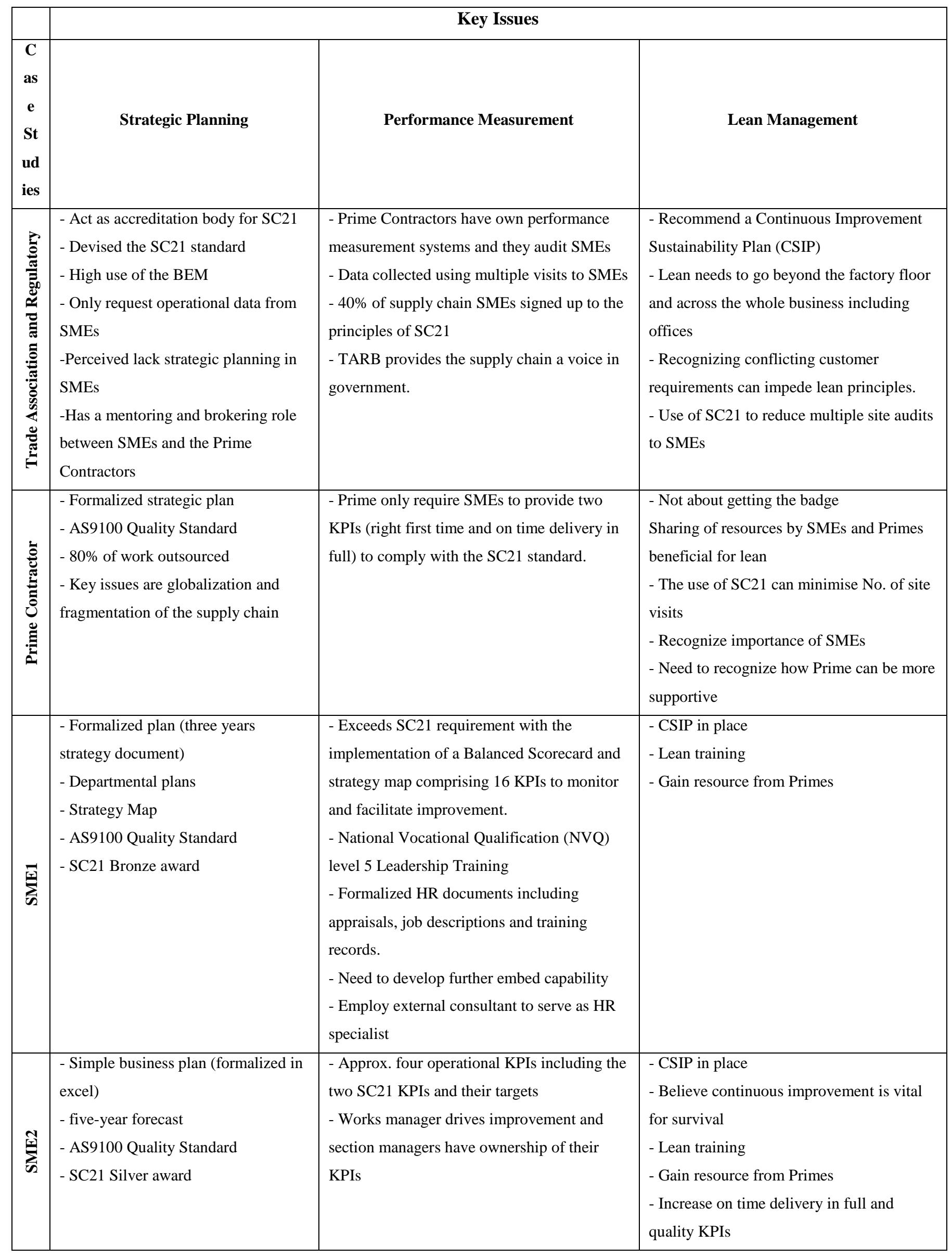




\begin{tabular}{|l|l|l|l|}
\hline \multirow{4}{*}{} & - No business plan & - Minimum requirement of on time delivery & - CSIP in place \\
- Very reactive managerial approach & in full and quality KPI & - CI driven by works manager. \\
- Lack of strategic focus & - View quality systems such as ISO 9001 and & - Limited lean workshops \\
- ISO9001 Quality Standard & SC21 as a badge to satisfy customers. & \\
& & Works mgr has ownership of KPIs & Gain resource from Primes \\
\hline
\end{tabular}

\section{Table 3 - Summary of Case Study Findings}

\subsection{Strategic Planning}

The aim of the SC21 initiative is to improve the competitiveness of the aerospace industry by raising the performance of its supply chains (SC21, 2019). The Prime contractor stated that $80 \%$ of the components within their products were outsourced and the organization relied heavily on SMEs to satisfy this demand. This meant that a longer term "partnering relationship" would be appropriate and SMEs' sustainability was recognized as vital for both the contractor and the SMEs. The Trade Association and Regulatory Body provided a mentoring and brokering role between SMEs and the prime contractors in their role as the accreditation body for SC21. To be eligible for accreditation, there was no requirement for the SMEs to have a formalized strategy. When asked about the percentage of SMEs that have a strategic plan, the TARB responded:

"ummm... we don't ask for that information from them, but generally the SMEs will have some sort of rough business plan, which they will then consider their strategic

$$
\text { plan”. (Project Manager, TARB) }
$$

Instead, they were scored against the Business Excellence Model framework as well as their delivery performance to the prime contractor in terms of time and quality.

The three SMEs were accredited to SC21 and had differing levels of formalized strategic planning and performance measurement systems. SME1 had a three-year strategy document aligned to a balanced scorecard which was tailored to the SME context. Its strategic intent was to grow the business by $50 \%$ in three years whilst maintaining gross profit margins.

"It's a fit for purpose document, suitable for an SME...we have a balance scorecard, and we also have a golden thread, so the objectives of the business are communicated internally", 
SME2 had a relatively simplistic two-page five-year business plan composed on Excel. The document included a group of performance indicators with their own targets.

“...it's an excel spreadsheet of about two pages. It's fairly general; it doesn't really go into huge amount of detail, but it's quite a generic document, which again, has specific targets that we hope to meet."

SME3 had no strategic plan and performance measurement system. It was very reactive in its planning having lost a major part of their order book due to an off-shoring decision by one of the Primes.

"Not really, because at the moment, due to our turnover being down, caused by one customer moving a big lump of manufacturing to China, we're desperately trying to find work to fill that void". "...if I was totally honest, and between you and me and the gatepost, my next strategic plan is to retire! (laughs)"

\subsection{Performance Measurement}

Within the aerospace industry, performance measurement took a growing relevance pulled by the very stringent quality standards. Prime contractors and their supply chain companies are often required to be accredited to AS9100. Such quality standards are applicable to the aerospace, defence and space industries but they are quite burdensome for SMEs. This happens because, as well as possessing all of the quality management attributes of ISO9001, they also require organizations to document their project, risk and configuration management procedures (AS9100, 2015). The SMEs in the case studies had been AS9100 accredited for several years, which was deemed a threshold requirement to trade with the prime contractors. It has been recognized for some time that the standard was a "curate's egg", good in terms of compliance but not so good in terms of bureaucracy and performance improvement. This shortfall often required Primes to visit SMEs and encourage them to work to their own bespoke standards with the possibility of SMEs subjected to several visits from Primes. The supplementary SC21 standard goes beyond compliance and looks for evidence of continuous improvement and, consequently, it implies a more holistic approach to performance measurement and management. 
According to the prime contractor, over $40 \%$ of its supply chain was registered with the SC21 programme. The SC21 initiative had a conceptual agreement with the Primes and it also aimed to minimize their site visits to SMEs which, although useful, were not in the spirit of lean as they could result in parallel reporting systems and increased bureaucracy for the SMEs. The SC21 award aims to give Primes a level of confidence in their supply chain so that site visits become unnecessary. In order to be awarded the SC21 standard an SME needs to demonstrate excellent PMS. Particular attention is given to the two criteria over a rolling twelve-month period: on time delivery in full (OTDIF) and right first time (RFT). In order to be awarded the bronze standard the SMEs need to achieve over 90\% OTDIF and over 98\% RFT. For the silver award, it is $95 \%$ and $99.5 \%$ respectively plus a score of greater than 400 points on the BEM framework. Two of the investigated SMEs (i.e., SME2 and SME3) monitored these KPIs and little else other than some rudimentary operational KPIs relating to cycle time and financial control. Nevertheless, they found this level of performance measurement beneficial to their organisation.

\begin{abstract}
"I would say that it's very, very valuable to the company in terms of we know what we're doing, we know where we are, we know where we're going, etc. etc...So to coin a phrase the other day, when I knew I was in the shit, but I knew exactly how deep! I've got to document that!” (Works Manager SME2)
\end{abstract}

SME1 went much further and developed a Balanced Scorecard including a strategy map aligned to their business strategy and twenty strategic KPIs belonging to the four BSC perspectives.

"I think this is really a decision which our Managing Director took...he was introduced to it by a customer, and I think our Managing Director looked at it and thought 'Well you know this could possibly give us an edge over a competitor and make us efficient in the meantime'. So I think that was his thinking behind it anyway" (Works Manager, SME1).

However, it was apparent that all managers and owners of SMEs had limited capability with respect to lean and performance measurement techniques. This required prime 
contractors to assist them in building capability. Throughout this capability building exercise, it became apparent that Prime could also learn lessons from SMEs through collaboration (Kourti, 2017; Kache and Seuring, 2014).

As the prime contractor becomes more dependent on the SMEs to realize their own strategies, the relationship evolves from an adversarial approach to a lean collaborative approach where costs can be removed from the supply chain in a mutually beneficial way. Prime contractors recognize that late delivery or quality issues are not always the fault of the SME.

\section{"Typically, when you peel that lid back and find out what the root cause is, probably about 50\% of the time isn't with the supplier, it's actually something that the customer. They haven't got the spec in time or the specification is not clear." (Prime, Supply Chain Director)}

As a consequence, during the SC21 process prime contractors offer their own resources and capabilities to assist SMEs to become more effective. This may take the form of benchmarking, training workshops or the secondment of staff to assist in the process. All of the investigated SMEs interviewed had benefitted from the assistance of their Prime Contractor.

Moreover, SMEs highlighted the need for investment in training and development to improve the capability of their staff in developing self-sustainability and creativity. The findings reveal that many employees, including managers, have been employed by their respective SME straight from school and lack formal management qualifications. Consequently, they have learned knowledge only directly "on the job" within the culture of their organization. This means that SMEs rely heavily on the Prime Contractor to provide resource and know how to facilitate knowledge exchange. SME1 has gone further in bridging the knowledge gap by by proactively investing in management development by sponsoring NVQ level 5 management qualifications that are gained via on-the-job learning equivalent to a master's degree level (Jenkins et al. 2003) for their key staff and lean training to all staff. SME1 also employed a human resources consultant to develop a robust appraisal system, which would include the 
identification of training needs and the facilitation of a possible succession planning strategy. The appraisal training actions were embedded within its Improvement Sustainability Plan.

\subsection{Lean Management}

The SC21 philosophy is based on lean principles. To promote this approach, the TARB requires SC21 accredited SMEs to maintain a continuous improvement sustainability plan (CSIP) and they supply templates for SMEs to use. According to our findings, however, lean has been adopted on the factory floor but less so in the office or business environment.

It is important to note that engineering is continually evolving and white-collar roles such as design, estimating, scheduling as well as finance and administration make up a significant composition of the workforce of an SME. When considering the extent of white-collar roles within SMEs, the project manager and the managing director (MD) of the trade association made important observations.

“I think I've seen a lot of people with lean programmes, and lean practices and a great sort of information boards, that are completely up to date around the factory and so on ... but you walk around the offices and it completely changes... I have seen very few truly lean organisations”. (Managing Director, TARB)

All case study SMEs had received support from their respective "Primes" to establish lean principles on the shop floor such as Kaizen, 5S and the "7 Wastes" improvement initiatives. However, there was an acknowledgement that all staff would benefit from training and development. SME 1 has been proactive and adopted and encouraged employee participation via internal and external lean training programmes.

"Training is key to achieving the goals... we need to get more training; broaden the horizons, more knowledge, pick up new ideas. I think it's very easy to become stale (Managing Director, SME1)" 
He also added that as well as training, ownership and accountability were of paramount importance in improving performance as it facilitates change within the organisation.

“Aah, it's improved significantly through ownership, that's a big factor. It's improved yes; ownership allows many things to change, rather than a single person driving changes at the top of the business." (Managing Director, SME1).

\section{Discussion}

The above findings reveal the paramount importance of collaboration between the companies belonging to the Aerospace Defence Security in ensuring SC21 success. Prior to the implementation of the SC21 framework, the use of quality management standards such ISO9001 and AS9100 were the main references, but there were insufficient for facilitating a closer cooperation between the supply chain partners. Additional vendor rated factory visits by prime contractors aimed at developing closer cooperation had an unintended consequence of adding duplication and bureaucracy which is what scholars cautioned against (McAdam, 2000; Garengo and Biazzo, 2013;). Moreover, within the aerospace manufacturing sector, despite practicing lean, JIT, quality management and performance improvement, lean SCM were not effectively fulfilled. There were relevant implementation issues such as the lack of coordination between supply chain partners, which was highlighted by the prime contractor as their responsibility. This supports the findings of Jasti and Kodali (2016) who argue that joint goals are vital for effective lean SCM. All of the stakeholders believed that SC21 provided the necessary joined up thinking in terms of removing the duplication of multiple site visits from SMEs who had several prime contractors as customers. In addition, having a common purpose of mutual benefit enabled prime contractors to release human capital to build capability and know-how in the participating SMEs. Another larger SME invested in formal management training programmes, which would promote empowerment to release potential to new ideas and innovation. These initiatives partly addressed some of the resource capability and concerns highlighted in the literature by implementing PMS (Smith and Bititci 2017; Garengo et al. 2005). The collaboration with external partners for the accreditation processes has been highlighted in the literature as vital in dealing with the complexities of different agendas and incentives amongst the partners (Anantaram and Guenes, 2004). The trade association 
has been credited with being an effective lobbying partner for the entire supply chain by providing a single voice to governments.

Even though the literature highlights the need to make lean management ubiquitous in a factory context (Hines et al. 2004), this research shows that it was notably absent within the offices of those factories, as highlighted by two of the senior members of the trade association who run the SC21 improvement programme. In fact, the literature on lean offices is limited with respect to empirical studies, which is surprising given that many allied roles such as estimating, production engineering and design are vital supporting processes for operational capability. Empowerment and ownership from an SME management perspective were identified as challenges for further embedding lean principles and high maturity in PMS (Smith and Bititci 2017).

The importance of senior management commitment is widely documented within the PMS literature (Garengo and Bititci 2007; Bourne, 2005), but it seems that, too often, lip service is paid to the concept. Notwithstanding that BEM frameworks score leadership highly for SMEs that have achieved either bronze or silver award, their absence of formalized business strategies is noticeable. The SC21 framework does not stipulate the presence of a strategic document even though it is only several sides of paper. The rationale for SMEs not having a strategy is a combination of the bureaucratic concerns highlighted by McAdam (2000), but also a dependency on repeat work from existing customers. With the spread of global competitive pressures across the supply chain, SMEs are beginning to lose substantial contracts to lower cost international suppliers, which makes strategic planning more important. Most of the SMEs are managed by the founder, or family members, and their workforce has often been employed at the SME since leaving school or has joined from another SME. This reinforces the problem of lack of effective use of performance measurement information and effective training of the SME workforce identified by the literature (Garengo et al. 2005; O'Regan et al. 2010). In the investigated companies, the lean principles have often been imported into the SMEs from the primes, and it has been very encouraging and could be regarded as a success for SC21. However, SMEs' focus, hitherto, has been on operational issues and strategy simply extends to increasing turnover by a pre-defined percentage on last year. More could be done with respect to 
upskilling the senior management of the SMEs for improving strategic planning and PMS.

\section{Conclusion}

This study has made several contributions to knowledge with respect to SCM and performance measurement within a SME aerospace precision engineering context. The first is that it has provided rich empirical evidence of a coherent LSCM framework known as SC21 which works collaboratively with prime contractors, a regulatory trade association and more than 800 participating SMEs. Such a framework addresses some of the challenges highlighted in the literature regarding the need for more coherent LSCM frameworks and for supply chain partners to have joint goals. The SC21 framework not only provides several levels of award including bronze, silver and gold, it facilitates knowledge sharing between the prime contractor and the SMEs within the supply chain. SC21 has been a successful approach in bridging the gap of differing agendas between supply chain partners to enable them to pursue joint goals in a postglobal financial crisis landscape for mutual gain with the support of the trade association.

The second contribution to knowledge was the rich empirical evidence of performance measurement frameworks such as the Business Excellence model and the balanced scorecard being adopted and utilised by SMEs which contradicts some of the literature that SMEs lack both resources and capability and find them bureaucratic.

All the SME case studies had mature quality management compliance systems in place which gave them a greater understanding of improvement than most SMEs. However, two of the SMEs were quite reactive and reliant on the SC21 trade association for templates to monitor their performance. The third SME was different in that it proactively developed a formalised strategy, adopted a balanced scorecard and invested in management and staff development to improve its competitive position.

\subsection{Research limitations}

The main limitation of this study is the number of SMEs involved in the empirical research. Although five cases were appropriate for a study, there are more than 850 SMEs are participating in the SC21 programme. A greater number of case studies could enable generalisable claims to be made but the paper makes a valid contribution. In 
addition to increasing the number of cases in subsequent studies, further research could involve analysing SC21 accredited organizations that have adopted design for six sigma and LSS tools. 


\section{References}

Algassem, F., Yang, Q.P. and Au, J. (2014), “Application of Lean Six Sigma principles to Food Distribution SMEs", American Academic and Scholarly Research Journal, 6(4), 251-258.

Anantaram B. Geunes J., (2004). "Collaboration and Coordination in Supply". Production and Operations Management, 13(1), 1-2.

Antony, J., Kumar, M., \& Labib, A. (2008). Gearing Six Sigma into UK manufacturing SMEs: results from a pilot study. Journal of the Operational Research Society, 59(4), 482-493.

Antony, J. (2012), “A SWOT analysis on Six Sigma: some perspectives from leading academics and practitioners", International Journal of Productivity and Performance Management, 61(6), 691-698

AS9100, (2018), Available from: http://as9100store.com/what-is-ISO-10007Configuration-Management.aspx (Accessed: 15th September 2018)

Assarlind, M., Gremyr, I. and Backman, K. (2013), "Multi-faceted views on a Lean Six Sigma application", International Journal of Quality and Reliability Management, 30(4), 387-402

Bhat, S., Gijo, E.V. and Jnanesh, N.A. (2014), "Application of Lean Six Sigma methodology in the registration process of a hospital", International Journal of Productivity and Performance Management, 63(5), 613-643.

Bititci, U. S., Garengo, P., Ates, A., Nudurupati, S. (2015). Value of maturity models in performance measurement. International Journal of Production Research, 53(10), 3062-3085.

Bourne, M.2005 Researching performance measurement system implementation: The dynamics of success and failure Production Planning and Control, 16(2), pp. 101113

Braziotis C., Tannock J.D.T. Bourlakis M (2017) Strategic and operational considerations for the Extended Enterprise: insights from the aerospace industry, Production Planning and Control, 28(4) 267-280

Browning, T.R., Heath, R.D. (2009). Reconceptualizing the effects of lean on production costs with evidence from the F-22 program. Journal of Operations Management, 27(1), 23-44

Chae B, (2009). Developing key performance indicators for supply chain: an industry perspective. Supply Chain Management: An International Journal, 14(6): 422-428.

Chakravorty, S. S., Shah, A. D. (2012). Lean Six Sigma (LSS): An implementation experience. European Journal of Industrial Engineering, 6(1), 118-137.

Collis, J., Hussey, R., (2003). Business Research. Palgrave: Basingstoke.

Conti, T. A. (2007). A history and review of the European Quality Award Model. The TQM magazine, 19(2), 112-128.

Dahlgaard, J. J., Chen, C. K., Jang, J. Y., Banegas, L. A., Dahlgaard-Park, S. M. (2013). Business excellence models: Limitations, reflections and further development. Total Quality Management \& Business Excellence, 24(5-6), 519-538.

Dissanayake, C.K., Cross, J.A. (2018), Systematic mechanism for identifying the relative impact of supply chain performance areas on the overall supply chain 
performance using SCOR model and SEM International Journal of Production Economics 201, 102-115

Drohomeretski, E., da Costa, S. E. G., de Lima, E. P., de Rosa Garbuio, P. A. (2014). Lean, Six Sigma and Lean Six Sigma: An analysis based on operations strategy. International Journal of Production Research, 52(3), 804-824.

EFQM (2018), European Foundation for Quality Management Excellence Model. Available at: http://www.efqm.org/, Accessed on the 3rd September 2018.

Eisenhardt, K.M., (1989). Building theory from case research, Academy of Management Review, 14(4), 532-50.

Funo, K.A., Muniz, J., Silva Marins, F.A., Salomon, V.A.P. (2011). Supply chain risk management: An exploratory research in Brazilian aerospace industry, International Journal of Value Chain Management, 5(3-4), 265-280

Garrido-Vega, P., Sacristán-Díaz, M., \& Magaña-Ramírez, L. M. (2016). Six Sigma in SMES with low production volumes. A successful experience in aeronautics. Universia Business Review, (51), 52-71.

Garengo P., Biazzo S., Bititci U., (2005). Performance Measurement Systems in SMEs: a review for a research agenda, International Journal of Management Reviews, 7(1), $25-47$.

Garengo P., Bititci U. (2007). Towards a contingency approach to performance measurement: an empirical study in Scottish SMEs, International Journal of Operations \& Production Management 27(8), 802-825

Garengo, P., Biazzo, S. (2013), From ISO quality standards to an integrated management system: An implementation process in SME, Total Quality Management and Business Excellence, 24(3-4), pp. 310-335

George, M. L. 2002. Lean Six Sigma: Combining Six Sigma Quality with Lean Production Speed. New York: McGraw Hill Professional. ISBN: 978- 0071385213

Gunasekaran, A., Patel, C. and McGayghey, R.E. (2004), "A framework for supply chain performance measurement", International Journal of Production Economics, 87(3), 333-347.

Gunasekaran, A., Patel, C., Tirtiroglu, E. (2001), "Performance measures and metrics in a supply chain environment", International Journal of Operations \& Production Management, 21(1/2), 71-87.

Hallam, C.R.A., Keating, J. (2014) Company self-assessment of lean enterprise maturity in the aerospace industry, Journal of Enterprise Transformation, 4(1), 5171

Hanson, J.D., Melnyk, S.A. Calantonr, R.A. (2011), "Defining and measuring alignment in performance management", International Journal of Operations \& Production Management, 31(10), 1089-1114.

Haque, B., James-Moore, M. (2005) Performance measurement experiences in aerospace product development processes, International Journal of Business Performance Management 7(1), 100-122

Harry, M., R. Schroeder (2006). Six SIGMA: The Breakthrough Management Strategy Revolutionizing the World's Top Corporations. New York: Dell Publishing. 
Heinicke, A. (2018) Performance measurement systems in small and medium-sized enterprises and family firms: a systematic literature review, Journal of Management Control 28(4), 457-502

Hines, P., Holwe, M., Rich, N., (2004). "Learning to evolve: a review of contemporary lean thinking", International Journal of Operations \& Production Management, 24 (10), 994-1011.

Huan, S. H., Sheoran, S. K., Wang, G. (2004). A review and analysis of supply chain operations reference (SCOR) model. Supply Chain Management: An International Journal, 9(1), 23-29.

Hussein, M., Gunasekaran, A., Laitinen, E.K., (1998). Management accounting system in Finish service firms. Technovation, 18(1), 57-67

Jasti, N.V.K., Kodali, R., 2015. A critical review of lean supply chain management frameworks: proposed framework. Production Planning \& Control, 26(13), 10511068.

Jenkins, A., Vignoles, A., Wolf, A., Galindo-Rueda, F. (2003). The determinants and labour market effects of lifelong learning. Applied economics, 35(16), 1711-1721.

Johnson, H.T., Kaplan, R.S., (1987). Relevance Lost. Boston: Harvard Business School Press.

Kache, F., Seuring, S. (2014) Linking collaboration and integration to risk and performance in supply chains via a review of literature reviews, Supply Chain Management 19, 664-682

Knapp, S. (2015), "Lean Six Sigma implementation and organisational culture", International Journal of health Care Quality Assurance, 28(8), 855-863.

Kaplan, R., Norton, D., (1996). Using the Balanced Scorecard as a Strategic Management System. Harvard Business Review, Jan-Feb. pp. 75-85.

Kaushik, P., Khanduja, D., Mittal, K. and Jaglan, P. (2012), “Application of Six Sigma methodology in a small and medium -sized manufacturing enterprise", TQM Journal, 24 (1), 4-16.

Kourti, I. (2017). Effective performance management of inter-organisational collaborations through the construction of multiple identities, International Journal of Business Performance Management, 18(2), 236-251

Kumar, M., Antony, J., Tiwari, M. K. (2011). Six Sigma implementation framework for SMEs - a roadmap to manage and sustain the change. International Journal of Production Research, 49(18), 5449-5467

Kumar, M., Antony, J., Singh, R. K., Tiwari, M. K., \& Perry, D. (2006). Implementing the Lean Sigma framework in an Indian SME: A case study. Production Planning \& Control, 17(4), 407-423.

Lamming, R., (1993). Beyond partnership: strategies for innovation and lean supply (Vol. 94). London: Prentice Hall.

Lincoln, Y.S., Guba, E.G., (1985). Naturalistic inquiry (Vol. 75). Sage.

Lorentz, H., Wong, C.Y., Hilmola, O.P. (2007). Emerging distribution systems in central and Eastern Europe: Implications from two case studies, International Journal of Physical Distribution \& Logistics Management, 37(8), 670-697. 
Machado, M.C., Mendes, E.F., Telles, R., Sampaio, P. 2018 Towards a new model for SME self-assessment: a Brazilian empirical study Total Quality Management and Business Excellence, 1-19

Martínez-Jurado, P.J., Moyano-Fuentes, J. (2014) Key determinants of lean production adoption: Evidence from the aerospace sector, Production Planning and Control 25(4), 332-345

McAdam, R. (2000). Quality Models in an SME Context. International Journal of Quality and Reliability Management, 17, 305-323.

Meredith, J. (1998). Building operations management theory through case and field research. Journal of operations management, 16(4), 441-454.

Miles, M. B., Huberman, A. M., (1994). Qualitative data analysis: An expanded sourcebook. Sage.

Neely A., Mills J., Platts J., Richards H., Gregory M., Bourne M., Kennerley M., (2000) "Performance measurement system design: developing and testing a process - based approach", International Journal of Operations \& Production Management, Vol. 20 Issue: 10, pp.1119-1145

Neely, A., (1999). The performance measurement revolution: why now and what next? International Journal of Operations and Production Management, 19, 205-228.

O'Regan, N., Stainer, L., Sims, M. (2010) Training in SMEs and its relationship to profitability, International, Journal of Human Resources Development and Management, 10(2), 166-181

Pande, P. S., Neuman, R. P., Cavanagh, R. R. (2014). The Six Sigma Way: How to maximize the impact of your change and improvement efforts. New York, NY: McGraw Hill. ISBN 978-0071497329.

Papadakis, I. S., (2006). Financial performance of supply chains after disruptions: an event study, Supply Chain Management: An International Journal, 11(1), 25-33.

Paraschi, E.P., Georgopoulos, A., Kaldis, P. (2019). Airport Business Excellence Model: A holistic performance management system Tourism Management 72, 352372

Pešalj, B., Pavlov, A., Micheli, P. (2018). The use of management control and performance measurement systems in SMEs: A levers of control perspective International Journal of Operations and Production Management, 38(11), 21692191

Peters M., Odenthal B., Schlick C.M. (2008) Design, Implementation and Evaluation of a Performance Measurement System for Virtual Enterprises in the Aerospace Industry. In: Ijioui R., Emmerich H., Ceyp M. (eds) Strategies and Tactics in Supply Chain Event Management. Springer, Berlin, Heidelberg

Powell, T.C., (1995). "Total quality management as competitive advantage: a review and empirical study", Strategic Management Journal, 16(1), 15-37

Prashar, A. (2014), "Adoption of Six Sigma DMAIC to reduce cost of poor quality", International Journal of Productivity and Performance Management, 63(1), 103126.

Quayle, M., (2003). A study of supply chain management practice in UK industrial SMEs, Supply Chain Management: An International Journal, 8(1), 79-86. 
Ruiz-Benitez, R., López, C., Real, J.C. (2018). Environmental benefits of lean, green and resilient supply chain management: The case of the aerospace sector, Journal of Cleaner Production, 167, 850-862

Saleheen, F., Habib, M.M., Hanafi, Z. (2018). Supply chain performance measurement model: A literature review, International Journal of Supply Chain Management 7(3), $70-78$

SC21, (2019). Available from: http://www.adsgroup.org.uk/pages/91430300.asp (Accessed on 15th 25th May 2016April 2019)

Shokri, A., Waring, T. S., \& Nabhani, F. (2016). Investigating the readiness of people in manufacturing SMEs to embark on Lean Six Sigma projects: An empirical study in the German manufacturing sector. International Journal of Operations \& Production Management, 36(8), 850-878.

Smith M., Bititci U.S. (2017) Interplay between performance measurement and management, employee engagement and performance, International Journal of Operations \& Production Management, 37(9), 1207-1228

Spekman, R., Davis E. W. (2016). "The Extended Enterprise: A Decade Later." International Journal of Physical Distribution \& Logistics Management 46(1), 43 61.

Suh, T. Kwon, I.-W.G., (2006). "Matter over mind: when specific asset investment affects calculative trust in supply chain partnership", Industrial Marketing Management, 35(2), 191-201.

Thakkar, J., Kanda, A., Deshmukh, S. G. (2013). Supply chain issues in SMEs: select insights from cases of Indian origin. Production Planning \& Control, 24(1), 47-71.

Thomas, A. J. Francis M., Fisher R. Byard P. (2016) "Implementing Lean Six Sigma to overcome the production challenges in an aerospace company", Production Planning \& Control, 27(7-8), 591-603

Thomas, A.J., Francis, M., Fisher, R., Byard, P. (2016), Implementing Lean Six Sigma to overcome the production challenges in an aerospace company, Production Planning and Control, 27(7-8), 591-603

Thonemann, U.W., Bradley, J.R., (2002). The Effect of Product Variety on SupplyChain Performance. European Journal of Operational Research 143, 548-556

Timans, W., Antony, J., Ahaus, K. and Solingen, R. 2012. Implementation of Lean Six Sigma in small and medium - sized manufacturing enterprises in the Netherlands. Journal of Operational Research Society 63, 339-353

Wang, F.K. and Chen, K. (2012), "Application of Lean Six Sigma to a panel equipment manufacturer", Total Quality Management, 23(4), 417-429

Yin, R.K. (2014), Case study research: design and methods, 5th ed. Thousand Oaks: Sage. 
Appendix 1

Interview Category Summary

\begin{tabular}{|c|c|c|}
\hline $\begin{array}{l}\text { SME Interview } \\
\text { Category }\end{array}$ & Broad Interview Questions & Literature \\
\hline Strategy & $\begin{array}{l}\text { Does your organisation have a } \\
\text { strategic plan documented? } \\
\text { - How did you first come across } \\
\text { performance measurement } \\
\text { frameworks? } \\
\text { Do internal/external stakeholders } \\
\text { influence your choice of key } \\
\text { performance indicators? }\end{array}$ & $\begin{array}{l}\text { Mc Adam (2000) } \\
\text { Gunasekaran et al } \\
(2004) \\
\text { Garengo et al. } \\
(2005) \\
\text { Kumar (2006) }\end{array}$ \\
\hline $\begin{array}{l}\text { Performance } \\
\text { Measurement }\end{array}$ & $\begin{array}{l}\text { Do you have any historical quality } \\
\text { management systems in place? } \\
\text { - Do you have a single measurement } \\
\text { framework? Why? Why not? } \\
\text { - What was your motivation for } \\
\text { implementing a performance } \\
\text { measurement framework? }\end{array}$ & $\begin{array}{l}\text { Garengo et al } \\
(2005) ; \\
\text { Kaplan and Norton } \\
\text { (1996) } \\
\text { Huan et al, (2004) } \\
\text { Manville (2007) }\end{array}$ \\
\hline $\begin{array}{l}\text { Lean \& Lean } \\
\text { Supply Chain }\end{array}$ & $\begin{array}{l}\text { - What is the process that you follow } \\
\text { in complying with SC } 21 \text { ? } \\
\text { - Do you need additional resource or } \\
\text { a dedicated member of staff to } \\
\text { maintain it? } \\
\text { - How does the concept of Lean } \\
\text { relate to performance } \\
\text { measurement/management } \\
\text { framework(s)? }\end{array}$ & $\begin{array}{l}\text { Anantaram and } \\
\text { Guenes (2004) } \\
\text { Chakravorty and } \\
\text { Shah (2012) } \\
\text { Pande et al. (2014); } \\
\text { Assarlind et al } \\
\text { (2013); } \\
\text { Bhat et al (2014); }\end{array}$ \\
\hline $\begin{array}{l}\text { Supply Chain } \\
\& \text { SC } 21 \\
\text { Implementation }\end{array}$ & $\begin{array}{l}\text { How many of your suppliers are } \\
\text { either signed up to SC } 21 \text { or are } \\
\text { considering it? } \\
\text { - How does your organisation } \\
\text { influence supplier performance? } \\
\text { How does your performance } \\
\text { measurement relate to your supply } \\
\text { chain? }\end{array}$ & $\begin{array}{l}\text { Lamming (1993) } \\
\text { Gunasekaran et al } \\
\text { (2004) } \\
\text { Thakkar et al } \\
\text { (2013); } \\
\text { Jasti and Kodali } \\
\text { (2015) }\end{array}$ \\
\hline Improvement & $\begin{array}{l}\text { - How important is continuous } \\
\text { improvement for your business? } \\
\text { - What changes have been necessary } \\
\text { to achieve performance } \\
\text { improvement? } \\
\text { - How do employees in your } \\
\text { organisation perceive } \\
\text { improvements? }\end{array}$ & $\begin{array}{l}\text { Hines et al (2004); } \\
\text { Jenkins et al (2004) } \\
\text { Chae (2009) } \\
\text { Su and Kwon } \\
(2006)\end{array}$ \\
\hline
\end{tabular}

